\title{
Global cropland monthly gross primary production in the year 2000
}

\author{
T. Chen ${ }^{1,2,3}$, G. R. van der Werf ${ }^{1}$, N. Gobron ${ }^{4}$, E. J. Moors ${ }^{5}$, and A. J. Dolman ${ }^{1}$ \\ ${ }^{1}$ Department of Earth Sciences, Faculty of Earth and Life Sciences, VU University Amsterdam, the Netherlands \\ ${ }^{2}$ International Center for Ecology, Meteorology and Environment (IceMe), School of Applied Meteorology, Nanjing \\ University of Information Science and Technology, Nanjing, China \\ ${ }^{3}$ School of Atmospheric Sciences, Nanjing University, Nanjing, China \\ ${ }^{4}$ Climate Risk Management Unit, Institute for Environment and Sustainability, European Commission Joint Research Center, \\ Ispra, Italy \\ ${ }^{5}$ Earth System Science and Climate Change Group, Wageningen University and Research Centre, Wageningen, the \\ Netherlands
}

Correspondence to: T. Chen (chentiexi@gmail.com)

Received: 10 June 2013 - Published in Biogeosciences Discuss.: 28 February 2014

Revised: 3 June 2014 - Accepted: 10 June 2014 - Published: 24 July 2014

\begin{abstract}
Croplands cover about $12 \%$ of the ice-free terrestrial land surface. Compared with natural ecosystems, croplands have distinct characteristics due to anthropogenic influences. Their global gross primary production (GPP) is not well constrained and estimates vary between 8.2 and 14.2 $\mathrm{Pg} \mathrm{C} \mathrm{yr}^{-1}$. We quantified global cropland GPP using a light use efficiency (LUE) model, employing satellite observations and survey data of crop types and distribution. A novel step in our analysis was to assign a maximum light use efficiency estimate $\left(\varepsilon_{\mathrm{GPP}}^{*}\right)$ to each of the 26 different crop types, instead of taking a uniform value as done in the past. These $\varepsilon_{\mathrm{GPP}}^{*}$ values were calculated based on flux tower $\mathrm{CO}_{2}$ exchange measurements and a literature survey of field studies, and ranged from 1.20 to $2.96 \mathrm{~g} \mathrm{C} \mathrm{MJ}^{-1}$. Global cropland GPP was estimated to be $11.05 \mathrm{Pg} \mathrm{Cyr}^{-1}$ in the year 2000 . Maize contributed most to this $\left(1.55 \mathrm{Pg} \mathrm{C} \mathrm{yr}^{-1}\right)$, and the continent of Asia contributed most with $38.9 \%$ of global cropland GPP. In the continental United States, annual cropland GPP (1.28 $\mathrm{Pg} \mathrm{C} \mathrm{yr}^{-1}$ ) was close to values reported previously (1.24 $\left.\mathrm{Pg} \mathrm{C} \mathrm{yr}^{-1}\right)$ constrained by harvest records, but our estimates of $\varepsilon_{\mathrm{GPP}}^{*}$ values were considerably higher. Our results are sensitive to satellite information and survey data on crop type and extent, but provide a consistent and data-driven approach to generate a look-up table of $\varepsilon_{\mathrm{GPP}}^{*}$ for the $26 \mathrm{crop}$ types for potential use in other vegetation models.
\end{abstract}

\section{Introduction}

The terrestrial biosphere assimilates an estimated 120$150 \mathrm{Pg} \mathrm{Cyr}^{-1}$ (Beer et al., 2010; Welp et al., 2011) as gross primary production (GPP). Roughly, half of the GPP is used for plant maintenance processes and is generally referred to as autotrophic respiration $\left(R_{\mathrm{a}}\right)$. The remainder is available for plant growth as net primary production (NPP), which is subsequently consumed mostly by heterotrophs $\left(R_{\mathrm{h}}\right)$ and fire.

Biochemical processes of photosynthesis at cell or leaf level are relatively well known, but accurate estimates of GPP at larger scales (regional or global) are still uncertain. Direct measurements of net ecosystem exchange (NEE: $\mathrm{GPP}-R_{\mathrm{h}}-R_{\mathrm{a}}$ ), such as eddy covariance measurements, suffer from the large spatial heterogeneity in the $\mathrm{CO}_{2}$ exchange between plants and the atmosphere which makes upscaling difficult. Therefore, current global GPP estimates still mainly rely on model results. However, considerable differences exist between various studies (Zhao et al., 2005; Ryu et al., 2011; Koffi et al., 2012; Beer et al., 2010), in particular for croplands. For example, Beer et al. (2010) reported global cropland GPP of $14.8 \mathrm{Pg} \mathrm{Cyr}^{-1}$ using flux tower measurements based on eddy covariance methods and several diagnostic models. In contrast, Saugier et al. (2001) estimated this number to be $8.2 \mathrm{Pg} \mathrm{Cyr}^{-1}$.

Croplands cover about $12 \%$ of the ice-free land surface globally (Ramankutty et al., 2008), contributing considerably to the global carbon cycle (Hicke et al., 2004). Additionally, 
the area occupied by croplands changes over time with consequences for global carbon stocks. For example, a large carbon sink was found in the abandoned croplands of the Soviet Union (Vuichard et al., 2008). Vice versa, deforestation is often related to the expansion of cropland (Morton et al., 2006) which leads to a decrease in aboveground biomass. However, croplands may also have a large capacity for carbon sequestration (Parr and Sullivan, 2011).

The light use efficiency (LUE) approach has been widely used to estimate GPP. Monteith (1972) developed this approach assuming that the growth in plant biomass is directly proportional to absorbed solar radiation. Since the 1970s, this LUE approach was mostly evaluated using field measurements of plant dry matter and solar radiation. The LUE approach was also applied to estimate net primary production (NPP) in large-scale models (Field et al., 1995; Knorr and Heimann, 1995; Potter et al., 1993; Ruimy et al., 1994, 1999). The LUE application was later extended to estimate GPP mostly because LUE is more likely to be fundamentally related to GPP, the direct outcome of photosynthesis (Prince and Goward, 1995; Ruimy et al., 1996; Running et al., 2000; Landsberg et al., 1997).

In the LUE approach, NPP or GPP is assumed proportional to the absorbed photosynthetically active radiation (PAR) at an efficiency rate, $\varepsilon$. Because $\varepsilon$ is affected by environmental factors, the maximum light use efficiency $\left(\varepsilon^{*}\right)$ (Haxeltine and Prentice, 1996; Potter et al., 1993), defined as an environmentally optimized $\varepsilon$, is widely used in models. Numerous studies have estimated $\varepsilon$ or $\varepsilon^{*}$ at site level (Supplement Table S1). In the parameterizations of models, $\varepsilon^{*}$ is more often used than $\varepsilon$ because $\varepsilon^{*}$ tends to be more stable between various plant types. Besides, subsequent environmental restrictions can be calculated using local environmental inputs. The LUE approach is thus widely used to estimate GPP or NPP from site level to large scales by combining satellitebased vegetation index measurements (Goerner et al., 2011; Potter et al., 1993; Xiao et al., 2005; Yuan et al., 2010; Zhao and Running, 2010; Field et al., 1995; Knorr and Heimann, 1995; Ruimy et al., 1994, 1996, 1999; Prince and Goward, 1995). Although all these models use the LUE concept, they often use different vegetation indices, $\varepsilon^{*}$ values, and may calculate environmental stresses in a different way.

Observational studies have illustrated that $\varepsilon$ varies widely between crops even when corrected for environmental stresses and nutrient limitation (Supplement Table S1). The LUE method is an empirical approach, requiring high quantity look-up tables of the key parameters to quantify the diversified ecosystems. However, in practice, the $\varepsilon^{*}$ in LUE models is assumed to be identical for all plant types or for major vegetation classes, such as croplands or grasslands (Goerner et al., 2011; Potter et al., 1993; Xiao et al., 2005; Yuan et al., 2010; Zhao and Running, 2010). Usually croplands have only one $\varepsilon^{*}$ value in models to represent the average condition, which introduces inevitable biases at local scales. This situation is largely due to two main constraints, suggesting also a strategy for improvement of the estimates. One is the paucity of land cover data, most of which does not offer sufficient detail to separate plant or crop types. The other is how to adequately use the large number of studies that have aimed to parameterize $\varepsilon^{*}$ using site level measurements.

This study aims to estimate global cropland GPP, using recently developed global cropland distribution data for the year 2000 to partition global croplands into 26 crop types. To improve the parameterization of the $\varepsilon_{\mathrm{GPP}}^{*}$ model, both eddy covariance flux measurements and a survey of previous reported $\varepsilon_{\mathrm{GPP}}^{*}$ values are used to generate a look-up table of $\varepsilon_{\mathrm{GPP}}^{*}$ for these 26 crop types.

\section{Methods and data sets}

\subsection{Introduction}

We used a biogeochemical model based on the LUE approach, the Carnegie-Ames-Stanford Approach (CASA, Potter et al., 1993; van der Werf et al., 2010). Croplands were separated into 26 crop types based on a new data set described in Sect. 2.2. We estimated $\varepsilon_{\text {GPP }}^{*}$ using 16 eddy covariance flux tower sites (FLUXNET) following Chen et al. (2011) and conducted a literature survey on previously reported $\varepsilon^{*}$ values. A combination of these two $\varepsilon^{*}$ resources yielded the look-up table of $\varepsilon_{\mathrm{GPP}}^{*}$ for the 26 crop types. These steps are explained in more detail below.

\subsection{LUE model and croplands data}

The CASA biogeochemical model with the version described in van der Werf et al. (2010) was used in this study. GPP was calculated by multiplying absorbed photosynthetically active radiation (PAR) and a light use efficiency coefficient, $\varepsilon$ (Monteith, 1972; Monteith and Moss, 1977):

$\mathrm{GPP}=\mathrm{PAR} \times \mathrm{fPAR} \times \varepsilon_{\mathrm{GPP}}^{*} \times T(\varepsilon) \times W(\varepsilon)$,

where fPAR (also known as fAPAR) is the fraction of PAR absorbed by vegetation. Environmental stresses related to temperature and water are indicated by $T(\varepsilon)$ and $W(\varepsilon)$ respectively. More details about the model structure can be found in Potter et al. (1993).

The monthly distribution of cropland-growth data of MIRCA2000 (monthly irrigated and rainfed crop areas; Portmann et al., 2010) was used as the map of global croplands at a 5 arcmin spatial resolution. The 26 crop types were separated in MIRCA2000. Correspondingly, 5 arcmin monthly fPAR data from the Joint Research Centre (JRC) were prepared based on original finer grid records (Gobron et al., 2010) which is further described in Sect. 2.3. $\varepsilon_{\mathrm{GPP}}^{*}$ was set crop specific, using the values estimated as described in Sect. 2.3. International Satellite Cloud Climatology Project (ISCCP) solar radiation data from the Goddard Institute for 
Space Studies (GISS) (Zhang et al., 2004) were used to generate PAR. Precipitation of the Global Precipitation Climatology Project (GPCP) version 1.1 (Huffman et al., 2001) and temperature of the GISS surface temperature analysis (Hansen et al., 1999) were employed to force environmental stress functions as described in Potter et al. (1993).

\subsection{The maximum light use efficiency, $\varepsilon_{\text {GPP }}^{*}$}

To fulfill the model requirements for the crop types, we needed to estimate and assign $\varepsilon_{\mathrm{GPP}}^{*}$ to these 26 crop types of the MIRCA2000 map. $\varepsilon_{\mathrm{GPP}}^{*}$ based on direct field measurements is ideal to ensure that the parameters in our model are consistent with regard to the vegetation index and environmental factors. Therefore, we applied a similar procedure as in our previous work (Chen et al., 2011) by constraining CASA modeled GPP with field GPP measurements from FLUXNET.

Eddy covariance instrumentation directly measures ecosystem net exchange (NEE), which can then be partitioned into GPP and respiration using various approaches (Reichstein et al., 2005; Lasslop et al., 2010). Combining satellite and eddy covariance tower measurements, $\varepsilon_{\mathrm{GPP}}^{*}$ can be directly estimated. FLUXNET offers a high level of global consistency between individual flux tower measurements (see http://www.fluxdata.org). The FLUXNET data set contains about 30 cropland sites. To accomplish our purpose of LUE evaluation, we included only those sites where PAR, temperature and precipitation records were available. Besides that, we also collected the rotation histories with details of growing periods and plant types from individual FLUXNET PI's. The information of the sites used in this study is listed in Supplement Table S2.

Satellite-based fPAR was used to indicate vegetation activity in our study, using JRC collocated fPAR products over the FLUXNET sites, available on http://fapar.jrc.ec.europa. eu/Home.php. JRC-fPAR data are generated based on the data collections of the SeaWiFS (Sea-viewing Wide Field-ofview Sensor) sensor on the SeaStar satellite and the MERIS (Medium Resolution Imaging Spectrometer) sensor on the Envisat (Environmental Satellite) platform of the European Space Agency. These collections have a 10-day temporal scale and cover 3 by 3 pixels, about $6 \mathrm{~km} \times 6 \mathrm{~km}$, around the central pixel where the FLUXNET sites are located. These data are specifically designed for validation of remote sensing products and models or for characterization of field sites. Because usually there are not sufficient fPAR observations on the ground, fPAR from the center pixel is assumed to represent the fPAR influencing the footprint of the tower.

To optimize $\varepsilon_{\mathrm{GPP}}^{*}$, we iteratively changed its value with steps of $0.05 \mathrm{~g} \mathrm{C} \mathrm{MJ}^{-1}$ and choose the $\varepsilon_{\mathrm{GPP}}^{*}$ with the lowest RMSE (root mean square error) between CASA and FLUXNET GPP:
$\mathrm{RMSE}=\left[\frac{1}{N} \sum_{n=1}^{N}\left(\mathrm{NEE}_{\mathrm{CASA}}-\mathrm{NEE}_{\mathrm{ECFT}}\right)^{2}\right]^{1 / 2}$.

This approach yielded direct estimates of $\varepsilon_{\mathrm{GPP}}^{*}$ for 8 crop types out of 26 crops due to the distribution of the FLUXNET sites. To fill in the gaps we conducted a survey of previous studies that reported $\varepsilon$ across a wide variety of crop types. However, these previous studies were quite different in their methodology. For example, solar radiation, intercepted PAR and absorbed PAR were interchangeably used to indicate radiation. Direct measurements of dry matter were often used to calculate production while we focused on GPP here. For consistency, we therefore used a conversion equation:

$\varepsilon_{\mathrm{GPP}}^{*}=\varepsilon_{\text {biomass }} \times R_{\mathrm{CB}} \times R_{\mathrm{NG}}^{-1} \times R_{\mathrm{ES}}$,

where $R_{\mathrm{CB}}$ is the carbon content per unit of dry biomass, $R_{\mathrm{NG}}$ is the ratio between NPP and GPP and $R_{\mathrm{ES}}$ indicates environmental stresses. $R_{\mathrm{CB}}$ was found to be quite stable within a 45-50\% range (Schlesinger, 1991). Magnussen and Reed (2004) suggested a conversion rate of 0.475 which was used here $\left(R_{\mathrm{CB}}=0.475\right)$. GPP could be roughly estimated by doubling NPP because autotrophic respiration $\left(R_{\mathrm{a}}\right)$ usually takes about half of GPP (Waring et al., 1998), but with substantial variability across plant types and sites (DeLucia et al., 2007; Litton et al., 2007; Luyssaert et al., 2007). NPP is usually treated as half the value of GPP in most analyses (Beer et al., 2010). Therefore, we used $R_{\mathrm{NG}}=0.5$ in this paper.

Most biomass measurements only consider aboveground dry matter (ADM). To calculate total dry matter (TDM) we used an ADM/TDM ratio of 0.8 (Gallagher and Biscoe, 1978; Steingrobe et al., 2001) when $\varepsilon$ values reported were based on ADM measurements only. The maximum light use efficiency concept assumes no environmental stresses, therefore, only the well-watered sites and those without diseases or drought were included in this study $\left(R_{\mathrm{ES}} \approx 1\right)$. As a result, $89 \varepsilon_{\mathrm{GPP}}^{*}$ values using Eq. (3) were converted based on literature, covering 21 crop types (Supplement Table S1).

\section{Results}

\subsection{Light use efficiency $\varepsilon_{\mathrm{GPP}}^{*}$}

The direct estimates of $\varepsilon_{\mathrm{GPP}}^{*}$ using FLUXNET crop sites are listed in Table 1. At these sites, the ratios between modeled and observed GPP varied between 0.86 and 1.23 and were on average $1.04 \pm 0.08$ (standard deviation - SD). The corresponding correlation coefficients of monthly modeled and observed GPP over each site were on average $0.85 \pm 0.14$. We summarized these measured $\varepsilon_{\mathrm{GPP}}^{*}$ and the ones derived from the literature for the 26 crop types in MIRCA2000 in Table 2. Of the 26 crop types, 8 were directly calculated in this paper, covering $55 \%$ of the global 


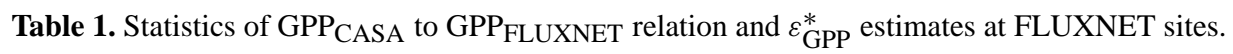

\begin{tabular}{|c|c|c|c|c|c|c|}
\hline $\begin{array}{l}\text { Site } \\
\text { code }\end{array}$ & $\begin{array}{l}\text { Crop } \\
\text { types }\end{array}$ & $\begin{array}{l}\text { Correlation } \\
\text { coefficient }\end{array}$ & $\begin{array}{c}\text { Standard } \\
\text { deviation }^{1}\end{array}$ & $\begin{array}{l}\text { Centered } \\
\text { RMSE }^{1}\end{array}$ & $\begin{array}{c}\text { GPP }_{\text {CASA }} / \\
\text { GPP }_{\text {FLUXNET }}\end{array}$ & $\begin{array}{c}\varepsilon_{\mathrm{GPP}}^{*} \\
\left(\mathrm{~g} \mathrm{CMJ}^{-1}\right)\end{array}$ \\
\hline \multirow[t]{3}{*}{ BE_Lon } & Sugar beet & 0.47 & 0.46 & 0.88 & 1.00 & 2.90 \\
\hline & Winter wheat & 0.72 & 0.75 & 0.69 & 0.95 & 2.40 \\
\hline & Potato & 0.98 & 0.39 & 0.61 & 1.12 & 1.50 \\
\hline CN_Du1 & Wheat & 0.83 & 0.56 & 0.62 & 1.10 & 1.65 \\
\hline \multirow[t]{3}{*}{ DE_Geb } & Rapeseed & 0.94 & 0.89 & 0.36 & 1.04 & 2.30 \\
\hline & Winter barley & 0.72 & 0.79 & 0.70 & 0.86 & 1.55 \\
\hline & Sugar beet & 0.90 & 0.84 & 0.43 & 1.23 & 1.00 \\
\hline \multirow[t]{2}{*}{ DE_Kli } & Rapeseed & 0.81 & 0.87 & 0.59 & 0.94 & 1.80 \\
\hline & Winter wheat & 0.95 & 0.83 & 0.33 & 1.20 & 2.45 \\
\hline DK_Ris & Winter wheat & 0.92 & 0.98 & 0.41 & 0.95 & 2.25 \\
\hline ES_ES2 & Rice & 0.94 & 0.94 & 0.33 & 1.01 & 2.90 \\
\hline FR_Gri & Winter wheat & 0.92 & 0.93 & 0.40 & 0.96 & 2.80 \\
\hline IE_Ca1 & Spring barley & 0.83 & 0.66 & 0.58 & 1.09 & 1.90 \\
\hline JP_Mas & Rice & 0.90 & 0.53 & 0.57 & 1.07 & 2.60 \\
\hline NL_Lan & Maize & 0.47 & 0.52 & 0.88 & 1.00 & 2.35 \\
\hline US_ARM & Wheat & 0.96 & 1.02 & 0.30 & 0.94 & 1.25 \\
\hline \multirow[t]{2}{*}{ US_Bo1 } & Soybean & 0.87 & 0.75 & 0.51 & 1.12 & 1.55 \\
\hline & Maize & 0.96 & 0.85 & 0.31 & 1.06 & 2.00 \\
\hline \multirow[t]{2}{*}{ US_Bo2 } & Maize & 0.99 & 0.87 & 0.16 & 1.09 & 2.90 \\
\hline & Soybean & 0.96 & 0.85 & 0.29 & 1.07 & 1.45 \\
\hline US_Ne1 & Maize & 0.90 & 0.61 & 0.53 & 1.11 & 2.95 \\
\hline \multirow[t]{2}{*}{ US_Ne2 } & Maize & 0.92 & 0.71 & 0.45 & 1.10 & 3.45 \\
\hline & Soybean & 0.79 & 0.63 & 0.63 & 1.07 & 1.75 \\
\hline \multirow[t]{2}{*}{ US_Ne3 } & Maize & 0.84 & 0.65 & 0.58 & 1.10 & 3.40 \\
\hline & Soybean & 0.74 & 0.64 & 0.68 & 1.03 & 1.80 \\
\hline
\end{tabular}

${ }^{1}$ Both modeled standard deviation and centered RMSE were nondimensionalized by dividing by the standard deviation of the corresponding observation. More details are in Sect. 3.2 of Taylor (2001).

cropland areas (Portmann et al., 2010). FLUXNET-based $\varepsilon_{\mathrm{GPP}}^{*}$ varied between crop types with potatoes having the lowest value $\left(1.5 \mathrm{~g} \mathrm{C} \mathrm{MJ}^{-1}\right)$ and maize having the highest $\left(2.84 \mathrm{~g} \mathrm{C} \mathrm{MJ}^{-1}\right)$. Our estimates and those of previous studies (Lobell et al., 2002; Chen et al., 2011; Supplement Table S1) thus confirm a higher LUE value for maize than most of other crops. On average our $\varepsilon_{\mathrm{GPP}}^{*}$ values are higher than the one used in Zhao and Running (2010) (i.e., $1.044 \mathrm{~g} \mathrm{C} \mathrm{MJ}^{-1}$ ) and the default values in the CASA model (i.e., $1 \mathrm{~g} \mathrm{C} \mathrm{MJ}^{-1}$ ), but are still within the range of values reported based on previous site measurements (e.g., Lobell et al., 2002; Supplement Table S1).

As shown in Fig. 1a, our direct estimates are generally lower than the literature-based values. We prefer to use our direct estimates based on FLUXNET measurements, because this enables us to upscale site level results to large domains using identical JRC fPAR data. To harmonize our $\varepsilon_{\mathrm{GPP}}^{*}$ values, a linear regression was calculated when both FLUXNET- and literature-based $\varepsilon_{\mathrm{GPP}}^{*}$ were available (Fig. 1b). The linear relation was further applied to generate the $\varepsilon_{\mathrm{GPP}}^{*}$ for the crop types that were not available in
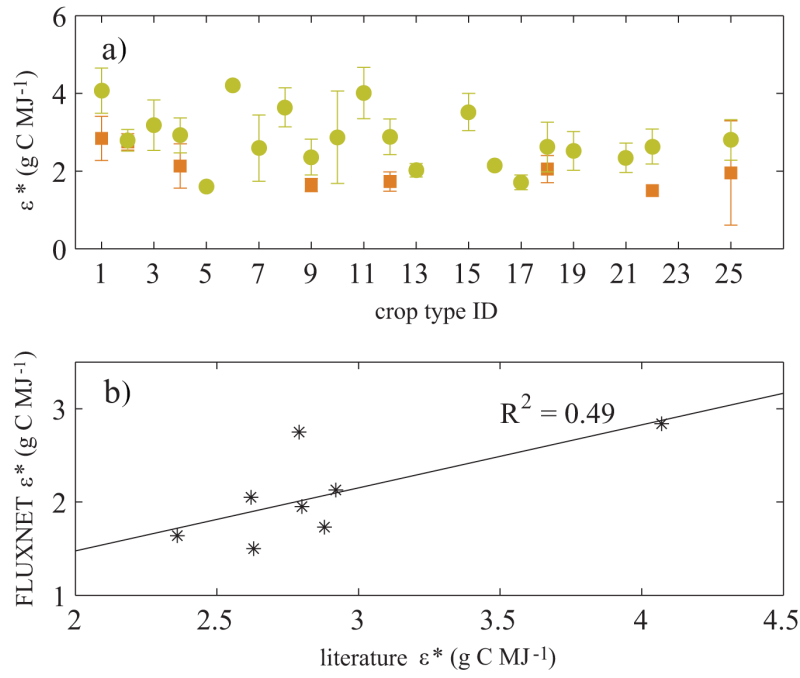

Figure 1. Maximum light use efficiency $\left(\varepsilon_{\mathrm{GPP}}^{*}\right.$ in $\left.\mathrm{g} \mathrm{C} \mathrm{MJ}^{-1}\right)$ for (a) different crop types based on FLUXNET sites (orange) and literature (green) with error bars representing two standard deviations of $\varepsilon_{\mathrm{GPP}}^{*}$. The corresponding crop types are given in Table 2. (b) Linear relation between FLUXNET-based and literature-based $\varepsilon_{\mathrm{GPP}}^{*}$ estimations for the eight crop types listed in Table 2. 
Table 2. $\varepsilon_{\mathrm{GPP}}^{*}$ used in our study and global cropland GPP estimates for various crop types.

\begin{tabular}{|c|c|c|c|c|c|c|}
\hline ID & $\begin{array}{l}\text { Crop } \\
\text { types }\end{array}$ & $\begin{array}{l}\varepsilon_{\mathrm{GPP}}^{*} \\
\pm \mathrm{SD}\end{array}$ & $\begin{array}{l}\varepsilon * \mathrm{GPP}_{\text {literature }} \\
\pm \mathrm{SD}\end{array}$ & $\varepsilon_{\mathrm{GP}}^{*}$ regress & $\begin{array}{l}\varepsilon_{\mathrm{GPP}}^{*}{ }_{\text {model }} \\
\left(\mathrm{PgC} \mathrm{yr}^{-1}\right)\end{array}$ & GPP \\
\hline 1 & Maize & $2.84 \pm 0.57$ & $4.07 \pm 0.58$ & 2.87 & 2.84 & 1.545 \\
\hline 2 & Rice & $2.75 \pm 0.21$ & $2.79 \pm 0.28$ & 2.01 & 2.75 & 1.514 \\
\hline 3 & Fodder grasses & & $3.18 \pm 0.65$ & 2.28 & 2.28 & 1.389 \\
\hline 4 & Wheat & $2.13 \pm 0.57$ & $2.92 \pm 0.45$ & 2.10 & 2.13 & 1.384 \\
\hline 5 & Others perennial & & 1.60 & 1.21 & 1.21 & 0.795 \\
\hline 6 & Cassava & & 4.20 & 2.96 & 2.96 & 0.612 \\
\hline 7 & Others annual & & $2.59 \pm 0.85$ & 1.87 & 1.87 & 0.508 \\
\hline 8 & Sugar cane & & $3.64 \pm 0.50$ & 2.59 & 2.59 & 0.494 \\
\hline 9 & Soybeans & $1.64 \pm 0.17$ & $2.36 \pm 0.46$ & 1.72 & 1.64 & 0.491 \\
\hline 10 & Pulses & & $2.87 \pm 1.19$ & 2.06 & 2.06 & 0.353 \\
\hline 11 & Sorghum & & $4.01 \pm 0.66$ & 2.83 & 2.83 & 0.272 \\
\hline 12 & Barley & $1.73 \pm 0.25$ & $2.88 \pm 0.46$ & 2.07 & 1.73 & 0.260 \\
\hline 13 & Oil palm & & $2.02 \pm 0.17$ & 1.49 & 1.49 & 0.210 \\
\hline 14 & Coffee & & & & 1.20 & 0.158 \\
\hline 15 & Millet & & $3.52 \pm 0.48$ & 2.51 & 2.51 & 0.134 \\
\hline 16 & Cocoa & & 2.14 & 1.57 & 1.57 & 0.132 \\
\hline 17 & Cotton & & $1.71 \pm 0.19$ & 1.28 & 1.28 & 0.123 \\
\hline 18 & Rapeseed & $2.05 \pm 0.35$ & $2.62 \pm 0.64$ & 1.89 & 2.05 & 0.115 \\
\hline 19 & Sunflower & & $2.52 \pm 0.50$ & 1.83 & 1.83 & 0.112 \\
\hline 20 & Rye & & & & 2.13 & 0.109 \\
\hline 21 & Groundnuts & & $2.34 \pm 0.38$ & 1.71 & 1.71 & 0.105 \\
\hline 22 & Potatoes & 1.50 & $2.63 \pm 0.45$ & 1.91 & 1.50 & 0.091 \\
\hline 23 & Citrus & & & & 1.20 & 0.064 \\
\hline 24 & Grapes & & & & 1.20 & 0.041 \\
\hline 25 & Sugar beet & $1.95 \pm 1.34$ & $2.80 \pm 0.52$ & 2.02 & 1.95 & 0.040 \\
\hline \multirow[t]{2}{*}{26} & Date palm & & & & 1.20 & 0.001 \\
\hline & Global & & & & & 11.05 \\
\hline
\end{tabular}

FLUXNET-based $\varepsilon_{\text {GPP }}^{*}$ as

$\varepsilon_{\mathrm{GPP}}^{*}{ }_{\mathrm{FLUXNET}}=0.6757 \times \varepsilon_{\mathrm{GPP}}^{*}{ }_{\text {literature }}+0.1252$.

Because $\varepsilon_{\mathrm{GPP}}^{*}$ should always be larger than zero, we kept the physically unrealistic offset (i.e., 0.1252) to best preserve the relation within the range of estimates. For five crop types we had neither FLUXNET nor literature values available. For rye, the same $\varepsilon_{\mathrm{GPP}}^{*}$ of wheat was assigned because rye is a member of the wheat tribe. The other four types (citrus, date palm, grapes and coffee) were all assigned $1.2 \mathrm{~g} \mathrm{C} \mathrm{MJ}^{-1}$, which is the lowest value of our estimates for other perennial crops $\left(1.21 \mathrm{~g} \mathrm{C} \mathrm{MJ}^{-1}\right)$ rounded to one decimal.

\subsection{Global cropland monthly GPP in the year 2000}

We calculated monthly GPP for these 26 crop types at 5 arcmin resolution for the year 2000, the only year for which the cropland distribution was available (Portmann et al., 2010). Global annual GPP amounts for each crop type as well as for all cropland combined are listed in Table 2. The annual global cropland GPP was $11.05 \mathrm{Pg} \mathrm{C} \mathrm{yr}^{-1}$ in the year 2000. This estimate was between the 8.2 and $14.8 \mathrm{Pg} \mathrm{C} \mathrm{yr}^{-1}$ reported previously by Saugier et al. (2001) and Beer et al. (2010), respectively. Maize, rice and wheat had the three highest GPP values for grains, contributing $40 \%$ of the global cropland GPP. Fodder grasses are the most important crop type that is not grain and ranked third in all crops. The eight crop types with $\varepsilon_{\mathrm{GPP}}^{*}$ based on FLUXNET sites contributed $49 \%$ of the global cropland GPP.

Figure 2 illustrates the global spatial distribution of annual cropland GPP. High GPP regions extend mostly in the warm humid or semi-humid plains of the Northern Hemisphere, such as the central and eastern part of United States, Europe, the eastern plain of China and the Ganges plain of South Asia. Per unit area, tropical regions had the highest GPP, such as in the lower reaches of the Ganges River over the contiguous areas of India and Bangladesh, and the lower reaches of the Niger River in Nigeria.

Asia produced over one third of global cropland GPP, which is more than two times that of any other continent (Table 3). Within the 26 types, rice contributed the most

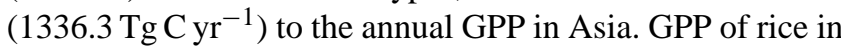
Asia contributed $88.3 \%$ of global rice GPP. North America and Europe accounted for respectively $16.6 \%$ and $16.2 \%$ of the global cropland GPP. The United States is the main producer of maize and soybean in the world, and this is reflected 
Table 3. Annual GPP $\left(\mathrm{Tg} \mathrm{C} \mathrm{yr}^{-1}\right)$ for different regions in the year 2000 .

\begin{tabular}{|c|c|c|c|c|c|c|}
\hline $\begin{array}{l}\text { Crop } \\
\text { types }\end{array}$ & $\begin{array}{r}\text { North } \\
\text { America }^{1}\end{array}$ & $\begin{array}{r}\text { South } \\
\text { America }\end{array}$ & Europe $^{2}$ & Asia & Africa & Oceania \\
\hline Maize & 504.2 & 277.2 & 204.6 & 342.6 & 215.5 & 1.0 \\
\hline Rice & 22.0 & 78.1 & 3.6 & 1336.3 & 73.2 & 0.9 \\
\hline Fodder grasses & 494.5 & 135.6 & 504.2 & 205.3 & 26.0 & 24.2 \\
\hline Wheat & 196.4 & 87.5 & 481.6 & 525.4 & 35.4 & 58.2 \\
\hline Others perennial & 34.2 & 64.7 & 55.9 & 505.1 & 121.1 & 14.3 \\
\hline Cassava & 9.9 & 103.9 & 0 & 143.6 & 354.4 & 0.8 \\
\hline Others annual & 31.9 & 37.2 & 117.7 & 215.6 & 95.8 & 9.5 \\
\hline Sugar cane & 85.2 & 180.8 & 0 & 186.8 & 30.4 & 11.0 \\
\hline Soybeans & 215.1 & 198.2 & 5.5 & 65.8 & 5.9 & 0.2 \\
\hline Pulses & 29.8 & 54.4 & 25.7 & 143.8 & 92.5 & 6.6 \\
\hline Sorghum & 54.1 & 28.3 & 1.4 & 70.4 & 112.0 & 5.6 \\
\hline Barley & 24.5 & 5.5 & 149.4 & 55.0 & 9.9 & 16.2 \\
\hline Oil palm & 2.6 & 6.9 & 0 & 138.0 & 60.8 & 2.1 \\
\hline Coffee & 33.2 & 56.2 & 0 & 36.0 & 30.7 & 1.6 \\
\hline Millet & 0.9 & 0.3 & 3.6 & 62.7 & 65.9 & 0.2 \\
\hline Cocoa & 6.2 & 28.7 & 0 & 14.2 & 80.3 & 2.9 \\
\hline Cotton & 31.6 & 11.9 & 1.5 & 54.2 & 21.3 & 2.2 \\
\hline Rapeseed & 16.2 & 0.4 & 36.6 & 56.4 & 0.1 & 5.4 \\
\hline Sunflower & 9.3 & 24.4 & 53.7 & 19.2 & 4.5 & 0.5 \\
\hline Rye & 1.7 & 0.7 & 98.4 & 7.2 & 0.4 & 0.2 \\
\hline Groundnuts & 6.5 & 3.8 & 0.1 & 55.4 & 39.4 & 0.2 \\
\hline Potatoes & 3.9 & 5.1 & 49.3 & 28.6 & 3.8 & 0.3 \\
\hline Citrus & 12.3 & 18.8 & 3.3 & 18.9 & 10.2 & 0.3 \\
\hline Grapes & 2.5 & 3.4 & 27.2 & 6.0 & 1.2 & 1.0 \\
\hline Sugar beet & 3.0 & 0.3 & 32.0 & 3.8 & 0.4 & 0 \\
\hline Date palm & 0 & 0 & 0 & 0.6 & 0.8 & 0 \\
\hline Total & 1831.7 & 1412.1 & 1855.4 & 4297.0 & 1492.0 & 165.5 \\
\hline Percent $(\%)$ & 16.6 & 12.8 & 16.8 & 38.9 & 13.5 & 1.5 \\
\hline
\end{tabular}

${ }^{1}$ North America includes Central America.

2 Europe does not contain Russia east of the Urals.

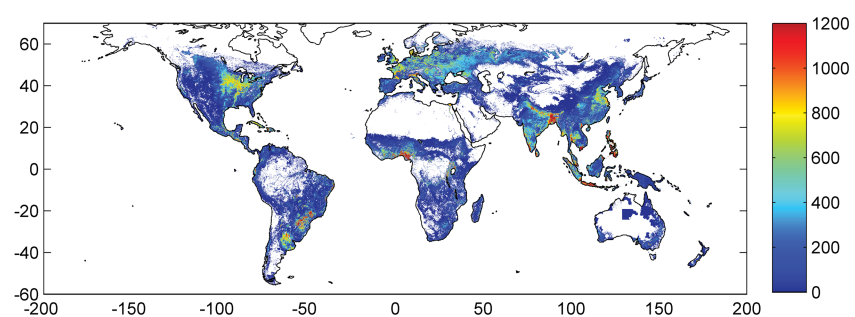

Figure 2. Spatial distribution of annual GPP flux $\left(\mathrm{g} \mathrm{C} \mathrm{m}^{-2} \mathrm{yr}^{-1}\right)$ for each 5 arcmin grid cell in the year 2000 with values capped at $1200 \mathrm{~g} \mathrm{C} \mathrm{m}^{-2} \mathrm{yr}^{-1}$. Annual GPP flux values of some grid cells in the tropics are larger than $2000 \mathrm{~g} \mathrm{C} \mathrm{m}^{-2} \mathrm{yr}^{-1}$.

in the proportion of maize and soybean (Table 3). Africa was the fourth most important region $(13.5 \%)$ with the most cassava GPP $(57.9 \%)$ of the world. The annual cropland GPP in South America (12.8\%) was very close to that of Africa. Maize and soybean contributed most to the cropland GPP in South America (Table 3). The cropland GPP in Oceania was the lowest of the continents, due to the small areas of croplands.

\section{Discussion}

After the initial development of the LUE approach (Monteith, 1972; Monteith and Moss, 1977) to estimate ecosystem production (GPP or NPP), considerable efforts have been made to evaluate $\varepsilon$ to meet the need of the model parameterizations. We chose to estimate $\varepsilon_{\text {GPP }}^{*}$ directly by combining FLUXNET measurements and JRC fPAR, the same vegetation index as we used in our model. Our estimates of $\varepsilon_{\mathrm{GPP}}^{*}$ are within the range reported previously by field measurements (Table 1; Supplement Table S1). In our model we treated the directly estimated $\varepsilon_{\mathrm{GPP}}^{*}$ as superior to the literature-based values. On average, the $\varepsilon_{\mathrm{GPP}}^{*}$ values based on biomass (dry matter) measurements are higher than our estimates based on FLUXNET observations. Therefore, we adjusted the literature-based $\varepsilon_{\mathrm{GPP}}^{*}$ values using ratios between the FLUXNET- and literature-based estimates when 
available. Because both the $\varepsilon_{\mathrm{GPP}}^{*}$ values based on biomass as well as the FLUXNET-based values are relatively high, the values finally used in our model are therefore higher than those used in other models (Zhao and Running, 2010; Lobell et al., 2002; Field et al., 1995; Potter et al., 1993). A look-up table of $\varepsilon_{\mathrm{GPP}}^{*}$ for 26 crop types was created, offering much more sophisticated parameters of the LUE empirical models than previous studies.

Global cropland GPP was estimated to be $11.05 \mathrm{Pg} \mathrm{C} \mathrm{yr}^{-1}$, which is within the range of previous studies (Beer et al., 2010; Saugier et al., 2001). Several model studies found that $\varepsilon_{\mathrm{GPP}}^{*}$ or $\varepsilon_{\mathrm{NPP}}^{*}$ values based on site measurements could not be used in models directly because this would lead to excessively high cropland GPP values (Lobell et al., 2002; Potter et al., 1993). For example, Potter et al. (1993) found that if $\varepsilon_{\mathrm{NPP}}^{*}$ would be set to $1.25 \mathrm{~g} \mathrm{C} \mathrm{MJ}^{-1}$ as in Heimann and Keeling (1989), annual NPP would be an unrealistic high $185 \mathrm{Pg} \mathrm{C} \mathrm{yr}^{-1}$. Therefore, a value of $0.5 \mathrm{~g} \mathrm{C} \mathrm{MJ}^{-1}$ for $\varepsilon_{\mathrm{NPP}}^{*}$ was initially used in CASA (Potter et al., 1993). Even if we double the $0.5 \mathrm{~g} \mathrm{CMJ}^{-1}$ number to account for the GPP / NPP ratio of about 2, the value is still much lower than the $\varepsilon_{\mathrm{GPP}}^{*}$ values we found here.

The difference between in situ measurements of $\varepsilon_{\mathrm{GPP}}^{*}$ and the values used in models may reflect model structural biases which have to be compensated for by adjusting parameters. Inventory-based estimates could be used to validate and improve crop models from local regions (Bandaru et al., 2013; Doraiswamy et al., 2007) to the continental scale (Lobell et al., 2002). Therefore, we echo the findings of Lobell et al. (2002) who used both CASA and harvest records. Cropland NPP for continental United States (excluding Alaska and Hawaii) was estimated to be $0.62 \mathrm{Pg} \mathrm{C} \mathrm{yr}^{-1}$, or $1.24 \mathrm{Pg} \mathrm{C} \mathrm{yr}^{-1}$ GPP by doubling NPP (Lobell et al., 2002). $\varepsilon_{\mathrm{NPP}}^{*}$ in Lobell et al. (2000) was estimated by constraining the model results with NPP based on harvest data across each county. In our estimations, GPP in the United States was $1.28 \mathrm{Pg} \mathrm{C} \mathrm{yr}^{-1}$, which is very close to the value obtained in Lobell et al. (2002). However, the $\varepsilon_{\mathrm{GPP}}^{*}$ values in Lobell et al. (2002) by doubling $\varepsilon_{\mathrm{NPP}}^{*}$ are still much smaller than the values we used here. There is therefore no conflict between field-based $\varepsilon_{\mathrm{GPP}}^{*}$ and the direct parameterization application in our model. The main distinction between the current and previous studies are the two main innovations of our study: (1) we used cropland areas distribution data to define the cropland types by month in order to distinguish the growing and fallow periods; and (2) we assigned each of the 26 crops a different $\varepsilon_{\mathrm{GPP}}^{*}$ value.

Compared with natural ecosystems, usually croplands have three important distinct features which influence their carbon exchange. First, plant (crop) types are much more homogeneous than natural ecosystems due to management practice of farmers. Second, the plant types change much faster than natural ecosystems due to crop rotation schemes used, which means the land cover type does not uniquely determine plant types as in more natural ecosystems. Third, planting, ploughing and harvesting activities change the ecosystems in croplands abruptly and leave land fallow for long periods, sometimes even during the growing season. Therefore, cropland distributions from survey data are the only option to separate crop rotation and planting times fully at present. However, the spatial resolution of these data is still larger than a single field, implying that one cell still contains several crop yields and types. These crops have different light use efficiencies in reality but are treated in models with the same vegetation index and environmental factors.

Uncertainties in our estimates were due to several aspects. First, the $\varepsilon^{*}$ varies between plant types and even changes within one crop type with changing environmental conditions. More evaluations of $\varepsilon_{\mathrm{GPP}}^{*}$ are required to constrain the parameters of different crop types. Second, the literaturebased $\varepsilon^{*}$ values depend on the choice of vegetation indices, such as fPAR, PRI (photochemical reflectance index), EVI (enhanced vegetation index), and different environment descriptions. Satellite fPAR is used in $\varepsilon_{\mathrm{GPP}}^{*}$ estimations due to the lack of ground fPAR observation, which brings uncertainties in consequence due to scale difference. In most cases, if a satellite's pixel contains roads or other human buildings, that may reduce the fPAR value and lead to an overestimated $\varepsilon_{\mathrm{GPP}}^{*}$ as well. Finally, we were unable to separate irrigated and rain-fed crops in our current approach. The exact magnitude of these uncertainties is impossible for us to quantify, but it should be possible when more $\varepsilon^{*}$ observations become available and when a systematic estimate of the error due to different vegetation indices is known in the future.

\section{Conclusions}

In this paper, we estimated global cropland GPP using a LUE model with improved input data and parameterization of $\varepsilon_{\mathrm{GPP}}^{*}$. A total of 26 crop types were separated in our model with different $\varepsilon_{\mathrm{GPP}}^{*}$ values compared to the previously default parameterization with a constant $\varepsilon_{\mathrm{GPP}}^{*}$ for all crop types. To meet the parameterization requirements, we evaluated $\varepsilon_{\mathrm{GPP}}^{*}$ based on FLUXNET data for eight crop types. We also performed a literature survey and gathered $89 \varepsilon_{\mathrm{GPP}}^{*}$ values that met our requirements necessary to harmonize these values. Our FLUXNET-based $\varepsilon_{\mathrm{GPP}}^{*}$ values are within the range of previous studies but are higher than those used in most LUE models. Finally, a look-up table of $\varepsilon_{\mathrm{GPP}}^{*}$ for the 26 crop types was created based on measurements.

$\varepsilon_{\mathrm{GPP}}^{*}$ (assumed equal to 2 times $\varepsilon_{\mathrm{NPP}}^{*}$ ) based on field measurements and the values used in vegetation models differ widely, as discussed by Potter et al. (1993), Ruimy et al. (1994) and Lobell et al. (2002). Our previous work (Chen et al., 2011) also highlighted the need to improve the LUE parameterization in vegetation models. In this study, we estimated global cropland annual GPP at $11.05 \mathrm{Pg} \mathrm{Cyr}^{-1}$ using field-based $\varepsilon_{\mathrm{GPP}}^{*}$. This estimate is in the middle of previous studies indicating 14.2 $\mathrm{Pg} \mathrm{C} \mathrm{yr}^{-1}$ by Beer et al. (2010) 
and $8.2 \mathrm{Pg} \mathrm{Cyr}^{-1}$ by Saugier et al. (2001). GPP in the United States was estimated to be $1.28 \mathrm{PgC}^{-1}$, close to the $1.24 \mathrm{Pg} \mathrm{Cyr}^{-1}$ reported by Lobell et al. (2002). Our results demonstrate a successful usage of directly estimated $\varepsilon_{\mathrm{GPP}}^{*}$ in a LUE-approach-based vegetation model. We only focused on the year 2000 because the cropland distribution data was only available for this year. Our improvements, separating croplands which are generally treated as one biome in global models into different plant types with corresponding spatial distribution and using more specific $\varepsilon_{\mathrm{GPP}}^{*}$ values for each type, may lead to more realistic cropland GPP estimates.

\section{The Supplement related to this article is available online at doi:10.5194/bg-11-3871-2014-supplement.}

Acknowledgements. We highly appreciate the help during data collection from PIs and co-workers of eddy flux sites, and the help with global cropland distribution data from Felix Portmann and Navin Ramankutty. A. J. Dolman and T. Chen acknowledge the support from the European Union grants FP7-226701 (project CARBO-EXTREME) and FP7-244240 (project CLIMAFRICA). G. R. van der Werf is supported by ERC grant number 280061. T. Chen acknowledges Xing CHEN's (Nanjing University) supervision and discussions. T. Chen thanks James Randerson and Maosheng Zhao for helpful advice and discussions. T. Chen acknowledges the support of the State Scholarship Fund of China Scholarship Council (CSC), National Key Basic Research Program of China (2010CB428506), National Natural Science Foundation of China (40875043), and the "Outstanding Ph.D. candidate" program of Nanjing University.

This work used eddy covariance data acquired by the FLUXNET community and in particular by the following networks: AmeriFlux (US Department of Energy, Biological and Environmental Research, Terrestrial Carbon Program (DE-FG02-04ER63917 and DE-FG02-04ER63911)), AfriFlux, AsiaFlux, CarboAfrica, CarboEuropeIP, CarboItaly, CarboMont, ChinaFlux, FLUXNETCanada (supported by CFCAS, NSERC, BIOCAP, Environment Canada, and NRCan), GreenGrass, KoFlux, LBA, NECC, OzFlux, TCOS-Siberia, USCCC. We acknowledge the financial support to the eddy covariance data harmonization provided by CarboEuropeIP, FAO-GTOS-TCO, iLEAPS, Max Planck Institute for Biogeochemistry, National Science Foundation, University of Tuscia, Université Laval and Environment Canada and US Department of Energy and the database development and technical support from Berkeley Water Center; Lawrence Berkeley National Laboratory; Microsoft Research eScience; Oak Ridge National Laboratory; University of California, Berkeley; and University of Virginia.

Edited by: U. Seibt

\section{References}

Bandaru, V., West, T. O., Ricciuto, D. M., and César Izaurralde, R.: Estimating crop net primary production using national inventory data and MODIS-derived parameters, ISPRS J. Photogramm., 80, 61-71, doi:10.1016/j.isprsjprs.2013.03.005, 2013.

Beer, C., Reichstein, M., Tomelleri, E., Ciais, P., Jung, M., Carvalhais, N., Rodenbeck, C., Arain, M. A., Baldocchi, D., Bonan, G. B., Bondeau, A., Cescatti, A., Lasslop, G., Lindroth, A., Lomas, M., Luyssaert, S., Margolis, H., Oleson, K. W., Roupsard, O., Veenendaal, E., Viovy, N., Williams, C., Woodward, F. I., and Papale, D.: Terrestrial gross carbon dioxide uptake: global distribution and covariation with climate, Science, 329, 834-838, doi:10.1126/science.1184984, 2010.

Chen, T. X., van der Werf, G. R., Dolman, A. J., and Groenendijk, M.: Evaluation of cropland maximum light use efficiency using eddy flux measurements in North America and Europe, Geophys. Res. Lett., 38, L14707, doi:10.1029/2011GL047533, 2011.

DeLucia, E. H., Drake, J. E., Thomas, R. B., and Gonzalez-Meler, M.: Forest carbon use efficiency: is respiration a constant fraction of gross primary production?, Glob. Change Biol., 13, 11571167, doi:10.1111/j.1365-2486.2007.01365.x, 2007.

Doraiswamy, P. C., Akhmedov, B., Beard, L., Stern, A., and Mueller, R.: Operational prediction of crop yields using MODIS data and products, International Archives of Photogrammetry, Remote Sensing and Spatial Information Sciences Special Publications, 2007.

Field, C. B., Randerson, J. T., and Malmstrom, C. M.: Global Net Primary Production - combining ecology and remotesensing, Remote Sens. Environ., 51, 74-88, doi:10.1016/00344257(94)00066-V, 1995.

Gallagher, J. N. and Biscoe, P. V.: Radiation absorption, growth and yield of Cereals, J. Agr. Sci., 91, 47-60, 1978.

Gobron, N., Belward, A., Pinty, B., and Knorr, W.: Monitoring biosphere vegetation 1998-2009, Geophys. Res. Lett., 37, L15402, doi:10.1029/2010GL043870, 2010.

Goerner, A., Reichstein, M., Tomelleri, E., Hanan, N., Rambal, S., Papale, D., Dragoni, D., and Schmullius, C.: Remote sensing of ecosystem light use efficiency with MODIS-based PRI, Biogeosciences, 8, 189-202, doi:10.5194/bg-8-189-2011, 2011.

Hansen, J., Ruedy, R., Glascoe, J., and Sato, M.: GISS analysis of surface temperature change, J. Geophys. Res-Atmos., 104, 30997-31022, doi:10.1029/1999JD900835, 1999.

Haxeltine, A. and Prentice, I. C.: A general model for the lightuse efficiency of primary production, Funct. Ecol., 10, 551-561, 1996.

Heimann, M. and Keeling, C. D.: A three-dimensional model of atmospheric $\mathrm{CO}_{2}$ transport based on observed winds: 2. Model description and simulated tracer experiments, in: Aspects of Climate Variability in the Pacific and the Western Americas, edited by: Peterson, D. H., American Geophysical Union, Washington DC, 237-275, 1989.

Hicke, J. A., Lobell, D. B., and Asner, G. P.: Cropland area and Net Primary Production computed from 30 years of USDA agricultural harvest data, Earth Interact., 8, 1-20, doi:10.1175/10873562(2004)008<0001:CAANPP>2.0.CO;2, 2004.

Huffman, G. J., Adler, R. F., Morrissey, M. M., Bolvin, D. T., Curtis, S., Joyce, R., McGavock, B., and Susskind, J.: Global precipitation at one-degree daily resolution from multisatellite 
observations, J. Hydrometeorol., 2, 36-50, doi:10.1175/15257541(2001)002<0036:GPAODD>2.0.CO;2, 2001.

Knorr, W. and Heimann, M.: Impact of Drought Stress and Other Factors on Seasonal Land Biosphere $\mathrm{CO}_{2}$ Exchange Studied through an Atmospheric Tracer Transport Model, Tellus B, 47, 471-489, doi:10.1034/j.1600-0889.47.issue4.7.x, 1995.

Koffi, E. N., Rayner, P. J., Scholze, M., and Beer, C.: Atmospheric constraints on gross primary productivity and net ecosystem productivity: Results from a carbon-cycle data assimilation system, Global Biogeochem. Cy., 26, GB1024, doi:10.1029/2010GB003900, 2012.

Landsberg, J. J., Prince, S. D., Jarvis, P. G., McMurtrie, R. E., Luxmoore, R., Medlyn, B. E.: "Energy conversion and use in forests: The analysis of forest production in terms of radiation utilization efficiency", in: The use of remote sensing in the modeling of forest productivity, Springer Netherlands, 273-298, 1997.

Lasslop, G., Reichstein, M., Papale, D., Richardson, A. D., Arneth, A., Barr, A., Stoy, P., and Wohlfahrt, G.: Separation of net ecosystem exchange into assimilation and respiration using a light response curve approach: critical issues and global evaluation, Glob. Change Biol., 16, 187-208, doi:10.1111/j.13652486.2009.02041.x, 2010.

Litton, C. M., Raich, J. W., and Ryan, M. G.: Carbon allocation in forest ecosystems, Glob. Change Biol., 13, 2089-2109, doi:10.1111/j.1365-2486.2007.01420.x, 2007.

Lobell, D. B., Hicke, J. A., Asner, G. P., Field, C. B., Tucker, C. J., and Los, S. O.: Satellite estimates of productivity and light use efficiency in United States agriculture, 1982-98, Glob. Change Biol., 8, 722-735, doi:10.1046/j.1365-2486.2002.00503.x, 2002.

Luyssaert, S., Inglima, I., Jung, M., Richardson, A. D., Reichstein, M., Papale, D., Piao, S. L., Schulzes, E. D., Wingate, L., Matteucci, G., Aragao, L., Aubinet, M., Beers, C., Bernhofer, C., Black, K. G., Bonal, D., Bonnefond, J. M., Chambers, J., Ciais, P., Cook, B., Davis, K. J., Dolman, A. J., Gielen, B., Goulden, M., Grace, J., Granier, A., Grelle, A., Griffis, T., Grunwald, T., Guidolotti, G., Hanson, P. J., Harding, R., Hollinger, D. Y., Hutyra, L. R., Kolar, P., Kruijt, B., Kutsch, W., Lagergren, F., Laurila, T., Law, B. E., Le Maire, G., Lindroth, A., Loustau, D., Malhi, Y., Mateus, J., Migliavacca, M., Misson, L., Montagnani, L., Moncrieff, J., Moors, E., Munger, J. W., Nikinmaa, E., Ollinger, S. V., Pita, G., Rebmann, C., Roupsard, O., Saigusa, N., Sanz, M. J., Seufert, G., Sierra, C., Smith, M. L., Tang, J., Valentini, R., Vesala, T., and Janssens, I. A.: $\mathrm{CO}_{2}$ balance of boreal, temperate, and tropical forests derived from a global database, Glob. Change Biol., 13, 2509-2537, doi:10.1111/j.1365-2486.2007.01439.x, 2007.

Magnussen, S. and Reed, D.: Modelling for estimation and monitoring, (FAO-IUFRO), 2004.

Monteith, J. L.: Solar-Radiation and Productivity in Tropical Ecosystems, J. Appl. Ecol., 9, 747-766, 1972.

Monteith, J. L. and Moss, C. J.: Climate and Efficiency of Crop Production in Britain, Philos. T. R. Soc. B, 281, 277-294, doi:10.1098/rstb.1977.0140, 1977.

Morton, D. C., DeFries, R. S., Shimabukuro, Y. E., Anderson, L. O., Arai, E., Espirito-Santo, F. D., Freitas, R., and Morisette, J.: Cropland expansion changes deforestation dynamics in the southern Brazilian Amazon, P. Natl. Acad. Sci. USA, 103, 14637-14641, doi:10.1073/pnas.0606377103, 2006.
Parr, J. F. and Sullivan, L. A.: Phytolith occluded carbon and silica variability in wheat cultivars, Plant Soil, 342, 165-171, doi:10.1007/s11104-010-0680-z, 2011.

Portmann, F. T., Siebert, S., and Doll, P.: MIRCA2000-Global monthly irrigated and rainfed crop areas around the year 2000: A new high-resolution data set for agricultural and hydrological modeling, Global Biogeochem. Cy., 24, GB1011, doi:10.1029/2008GB003435, 2010.

Potter, C. S., Randerson, J. T., Field, C. B., Matson, P. A., Vitousek, P. M., Mooney, H. A., and Klooster, S. A.: Terrestrial ecosystem production: A process model-based on global satellite and surface data, Global Biogeochem. Cy., 7, 811-841, doi:10.1029/93GB02725, 1993.

Prince, S. D. and Goward, S. N.: Global primary production: A remote sensing approach, J. Biogeogr., 22, 815-835, 1995.

Ramankutty, N., Evan, A. T., Monfreda, C., and Foley, J. A.: Farming the planet: 1. Geographic distribution of global agricultural lands in the year 2000, Global Biogeochem. Cy., 22, GB1003, doi:10.1029/2007GB002952, 2008.

Reichstein, M., Falge, E., Baldocchi, D., Papale, D., Aubinet, M., Berbigier, P., Bernhofer, C., Buchmann, N., Gilmanov, T., Granier, A., Grunwald, T., Havrankova, K., Ilvesniemi, H., Janous, D., Knohl, A., Laurila, T., Lohila, A., Loustau, D., Matteucci, G., Meyers, T., Miglietta, F., Ourcival, J. M., Pumpanen, J., Rambal, S., Rotenberg, E., Sanz, M., Tenhunen, J., Seufert, G., Vaccari, F., Vesala, T., Yakir, D., and Valentini, R.: On the separation of net ecosystem exchange into assimilation and ecosystem respiration: review and improved algorithm, Glob. Change Biol., 11, 1424-1439, doi:10.1111/j.1365-2486.2005.001002.x, 2005.

Ruimy, A., Saugier, B., and Dedieu, G.: Methodology for the estimation of terrestrial net primary production from remotely sensed data, J. Geophys. Res-Atmos., 99, 5263-5283, doi:10.1029/93JD03221, 1994.

Ruimy, A., Dedieu, G., and Saugier, B.: TURC: A diagnostic model of continental gross primary productivity and net primary productivity, Global Biogeochem. Cy., 10, 269-285, doi:10.1029/96GB00349, 1996.

Ruimy, A., Kergoat, L., Bondeau, A., and Intercomparison, P. P. N. M.: Comparing global models of terrestrial net primary productivity (NPP): analysis of differences in light absorption and lightuse efficiency, Glob. Change Biol., 5, 56-64, doi:10.1046/j.13652486.1999.00007.x, 1999.

Running, S. W., Thornton, P., Nemani, E. R., and Glassy, J. M.: Global terrestrial gross and net primary productivity from the Earth Observing System, in: Methods in ecosystem science, edited by: Sala, O. E., Jackson, R. B., Mooney, H. A., and Howarth, R. W., Springer, New York, 44-57, 2000.

Ryu, Y., Baldocchi, D. D., Kobayashi, H., van Ingen, C., Li, J., Black, T. A., Beringer, J., van Gorsel, E., Knohl, A., Law, B. E., and Roupsard, O.: Integration of MODIS land and atmosphere products with a coupled-process model to estimate gross primary productivity and evapotranspiration from $1 \mathrm{~km}$ to global scales, Global Biogeochem. Cy., 25, GB4017, DOI:10.1029/2011GB004053, 2011.

Saugier, B., Roy, J., and Mooney, H. A.: Estimations of global terrestrial productivity: converging toward a single number?, in: Terrestrial global productivity, edited by: Roy, J., Saugier, B., and Mooney, H. A., Academic Press, San Diego, 543-557 2001. 
Schlesinger, W. H.: Biogeochemistry, an Analysis of Global Change, Academic Press, New York, USA, 1991.

Steingrobe, B., Schmid, H., Gutser, R., and Claassen, N.: Root production and root mortality of winter wheat grown on sandy and loamy soils in different farming systems, Biol. Fert. Soils, 33, 331-339, doi:10.1007/s003740000334, 2001.

Taylor, K. E.: Summarizing multiple aspects of model performance in a single diagram, J. Geophys. Res-Atmos., 106, 7183-7192, doi:10.1029/2000JD900719, 2001.

van der Werf, G. R., Randerson, J. T., Giglio, L., Collatz, G. J., Mu, M., Kasibhatla, P. S., Morton, D. C., DeFries, R. S., Jin, Y., and van Leeuwen, T. T.: Global fire emissions and the contribution of deforestation, savanna, forest, agricultural, and peat fires (19972009), Atmos. Chem. Phys., 10, 11707-11735, doi:10.5194/acp10-11707-2010, 2010.

Vuichard, N., Ciais, P., Belelli, L., Smith, P., and Valentini, R.: Carbon sequestration due to the abandonment of agriculture in the former USSR since 1990, Global Biogeochem. Cy., 22, doi:10.1029/2008GB003212, 2008.

Waring, R. H., Landsberg, J. J., and Williams, M.: Net primary production of forests: a constant fraction of gross primary production?, Tree Physiol, 18, 129-134, doi:10.1093/treephys/18.2.129, 1998.

Welp, L. R., Keeling, R. F., Meijer, H. A. J., Bollenbacher, A. F., Piper, S. C., Yoshimura, K., Francey, R. J., Allison, C. E., and Wahlen, M.: Interannual variability in the oxygen isotopes of atmospheric $\mathrm{CO}_{2}$ driven by El Nino, Nature, 477, 579-582, doi:10.1038/nature10421, 2011.
Xiao, X. M., Zhang, Q. Y., Hollinger, D., Aber, J., and Moore, B.: Modeling gross primary production of an evergreen needle leaf forest using MODIS and climate data, Ecol. Appl., 15, 954-969, doi:10.1016/j.rse.2004.03.010, 2005.

Yuan, W. P., Liu, S. G., Yu, G. R., Bonnefond, J. M., Chen, J. Q., Davis, K., Desai, A. R., Goldstein, A. H., Gianelle, D., Rossi, F., Suyker, A. E., and Verma, S. B.: Global estimates of evapotranspiration and gross primary production based on MODIS and global meteorology data, Remote Sens. Environ., 114, 14161431, doi:10.1016/j.rse.2010.01.022, 2010.

Zhang, Y. C., Rossow, W. B., Lacis, A. A., Oinas, V., and Mishchenko, M. I.: Calculation of radiative fluxes from the surface to top of atmosphere based on ISCCP and other global data sets: Refinements of the radiative transfer model and the input data, J. Geophys. Res-Atmos., 109, D19105, doi:10.1029/2003JD004457, 2004.

Zhao, M. S. and Running, S. W.: Drought-induced reduction in global terrestrial net primary production from 2000 through 2009, Science, 329, 940-943, doi:10.1126/science.1192666, 2010.

Zhao, M. S., Heinsch, F. A., Nemani, R. R., and Running, S. W.: Improvements of the MODIS terrestrial gross and net primary production global data set, Remote Sens. Environ., 95, 164-176, doi:10.1016/j.rse.2004.12.011, 2005. 